\title{
Posterior Tongue Carcinoma
}

National Cancer Institute

\section{Source}

National Cancer Institute. Posterior Tongue Carcinoma. NCI Thesaurus. Code C8407.

A carcinoma that arises from the base of the tongue. Representative examples include squamous cell carcinoma, adenoid cystic carcinoma, and mucoepidermoid carcinoma. 